1 Sağlık Bilimleri Üniversitesi, Bursa Yüksek Ihtisas Eğitim ve Araştırma Hastanesi, Çocuk Sağlığı ve Hastalıkları Anabilim Dalı, Neonatoloji Bilim Dalı Bursa Türkiye

Sorumlu yazar yazışma adresi:

Ipek Güney Varal: Sağlık Bilimleri Üniversitesi, Bursa Yüksek İhtisas Eğitim ve Araştırma Hastanesi, Cocuk Sağlığı ve Hastalıkları Anabilim Dalı, Neonatoloji Bilim Dalı Bursa Türkiye

E-mail:ipekguneyvaral@gmail.com

Geliş tarihi/Received: $\quad$ 07.01.2020 Kabul tarihi/Accepted: 16.01.2020 Yayın hakları Güncel Pediatri'ye aittir.

Güncel Pediatri 2020;18(1):1-14
PRETERM ve TERM INFANTLARDA INHALE NITRIK OKSITT SONUÇLARI: ÜÇÜNCÜ DÜZEY YENIDOĞAN YOĞUN BAKIM ÜNITESINDEKI DÖRT YILLIK DENEYIM

\section{Outcomes of Inhaled Nitric Oxide in Preterm and Term Infants: A Four-Year Experience in a Tertiary Neonatal Unit}

İpek Güney Varal ${ }^{1}$ (0000-0002-3298-066X), Pelin Doğan ${ }^{1}(0000-$ 0003-4926-7657)

$\ddot{O} Z$

GİRIŞ ve AMAÇ: Bu çalışmada pulmoner hipertansiyon (PH) kliniği ile karakterize olan preterm ve term infantların, inhale nitrik oksit (iNO) tedavisine yanıtlarındaki etkinliğin değerlendirilmesi amaçlanmıştır.

YÖNTEM ve GEREÇLER: Çalışma kohortu 2015-2019 yılları arasında iNO tedavisi alan hastalardan oluşmuştur, hastalar gestasyon haftaları ve PH tanısının zamanına göre sınıflandırılmıştır.

BULGULAR: Çalışmaya toplamda 56 vaka dahil edilmiştir. iNO öncesi ve iNO sonrası ortalama hava yolu basınç değerleri ve oksijenasyon indeksi preterm infantların grubunda anlamlı düzeyde yüksek bulundu ( $\mathrm{p}$ $<0.05)$. Erken PH tanis1 alan grupta ortalama gestasyon haftası $(\mathrm{GH})$ ve doğum ağırlığı (DA) daha yüksek bulundu. INO tedavisine yanıt veren grupta GH'ları ve DA'nın belirgin yüksek oldugu izlendi ( $p<0.05)$. INO tedavisine yanıt alınamayan hastaların genellikle tanıları term bebeklerde diafragma hernisi iken pretermlerde sepsisdi.

TARTIŞMA ve SONUÇ: Term infantlarda İNO tedavisine daha iyi yanıt alınmakla beraber pretermlerde de İNO tedavisine erken başlanması ile daha iyi yanıt alınabilir.

Anahtar Kelimeler: inhale nitrik oksit, preterm, pulmoner hipertansiyon 


\section{ABSTRACT}

INTRODUCTION: This study aimed at assessing the data of term and preterm neonates with pulmonary hypertension $(\mathrm{PH})$ to characterise patients and the effectiveness of inhaled nitric oxide (iNO).

MATERIALS and METHODS: The study cohort treated with iNO between 2015 and 2019 was categorized into two groups according to the gestational age (GA) and timing of PH.

RESULTS: Overall 56 neonates were enrolled. Pre-iNO, post-iNO mean airway pressure values, and oxygenation index were significantly higher in the preterm group $(p<0.05)$. Mean GA and birth weight of the infants who had early PH diagnosis were higher. Positive responders were more likely to have higher GA as well as higher birth weight $(p<0.05)$. Non-responders were mostly diagnosed with diaphragmatic hernia in term infants and with sepsis in preterm infants

CONCLUSIONS: Despite term infants have higher positive response rate to treatment, initiating early treatment will increase the rate of positive response in preterm infants.

Key words: inhale nitric oxide, preterm, pulmonary hypertension 


\section{INTRODUCTION}

Nitric oxide (NO) molecule was found out 30 years ago and shortly after the discovery of NO, known as endothelial-derived relaxing factor, studies showed that it is a pulmonary-specific vasodilator (1). NO administered via inhalation (iNO) is a fat soluble, unstable, free radical gas. It is a small molecule that can be easily transferred through cell membranes; its half life is short and is expressed in seconds (2). Endogenous NO synthesis in neonates is induced by various events such as birth, stress, oxygen increase, or sepsis and formed via nitric oxide synthase, and it causes vasodilatation in smooth muscle cells via cGMP. iNO provides selective vasodilation in the pulmonary veins with its selective effect characteristic, and it also increases blood flow in the alveoli by decreasing the ventilation perfusion mismatch with its micro-selective effect (3).

The use of iNO improves oxygenation in neonates with persistent pulmonary hypertension (PH) (4). Persistent $\mathrm{PH}$ arises in neonates either as a primary or secondary condition to respiratory distress syndrome, meconium aspiration, sepsis, or birth asphyxia. (5-7). It is characterized by persistently increased pulmonary vascular resistance and arterial pressure that is associated with extrapulmonary right-to-left shunting leading to hypoxemic respiratory failure in tertiary neonatal intensive care units (NICUs). iNO is an effective but costly therapy which was approved for only late preterm and term infants with $\mathrm{PH}$; however, off-label use of iNO has become widespread as $5 \%-7 \%$ cases in preterm infants. $(8,9)$. In term and preterm infants, iNO is used to treat PH caused by various reasons (10). Cochrane review reported that iNO use improves oxygenation in term and late preterm infants, whereas it does not have an effect on mortality and length of hospital stay and is also ineffective in smaller preterm infants $(11,12)$.

The primary objective of this study is to characterize the term and preterm cases in whom we

used iNO for 4 years in the neonatal intensive care unit. The secondary objective is to identify factors associated with improved outcomes and favourable response to iNO therapy and to evaluate our iNO practice. 


\section{MATERIALS and METHODS}

A retrospective-cohort study was conducted at the University of Health Sciences, Bursa Yuksek Ihtisas Teaching Hospital between 2015 and 2019 after approval of the study by the local ethics committee. We included term and preterm infants treated with iNO in our NICU. Infants who had major congenital cardiac as well as other major anomalies were excluded. The infants were categorized into two groups: Group 1, gestation age (GA) <34 weeks and Group $2, \mathrm{GA} \geq 34$ weeks. iNO treatment was initiated under inadequate oxygen supply conditions with conventional mechanical ventilation strategies or severe respiratory failure [mean airway pressure (MAP) of $\geq 10$ or oxygenation index of $\geq 25$ ]. Oxygenation index (OI) was calculated as $\left(\mathrm{MAP}\left[\mathrm{cm} \mathrm{H}_{2} \mathrm{O}\right] \times\right.$ fraction of inspired oxygen $\left.\left[\mathrm{FIO}_{2}\right] \times 100\right) /$ partial pressure of oxygen in arterial blood $\left(\mathrm{PaO}_{2}\right)(\mathrm{mmHg})$. Measured oxygen saturation difference between the pre-ductal and post-ductal points in all infants was above $10 \%$. Echocardiography (ECHO) was performed in some patients to measure $\mathrm{PH}$ and make a definite diagnosis and exclude the diagnosis of congenital heart diseases. iNO treatment was continuously administered intratracheally during mechanical ventilation. The treatment was started at a dose of $20 \mathrm{ppm}$, and patients who had $\mathrm{FiO}_{2}$ reduced to $\geq 0.20$ during the $1^{\text {st }}$ hour of treatment were considered as positive responders. In positive responders, the treatment was kept at 20 ppm until OI reached $<10$ and $\mathrm{FiO}_{2}$ reached $<60$; thereafter, weaning was decreasing every 4 to 6 hours. After 1 hour, if $\mathrm{FiO}_{2}$ level did not change or decreased to $<0.10$ despite the treatment, the treatment was terminated according to the protocol. The patients were classified into two groups according to the initiation time of iNO treatment as early (iNO initiation at $\leq 3$ days of age) or late (at $>3$ days of age).

The following data were recorded: maternal medical history, prenatal demographics, antenatal steroid administration, GA, birth weight, gender, mode of delivery, Apgar score at $1^{\text {st }}$ and $5^{\text {th }}$ min, diagnoses, hospital stay durations, and mortality data. In addition, data related to iNO use; initiation time, treatment responses, treatment duration and MAP before (pre-iNO) and 2 hours after (post-iNO), $\mathrm{FiO}_{2}$, and $\mathrm{OI}$ were recorded. Based on these values, intra- and intergroup comparisons were performed to determine the "iNO responder" group. 
Statistical analyses: Statistical analyses of the data were performed using the Statistical Package for the Social Sciences (SPSS) version 20.0 software (SPSS Inc., Chicago, IL, USA). All the continuous values were presented as the median (interquartile range, IQR) and mean \pm standard deviation, where suitable. The categorical values were presented as the frequency and percentage. Chi-square analysis and Fisher's exact test was used for comparing categorical variables among the groups. Student's t-test was used for continuous variables and Mann-Whitney U was used for comparing nonparametric variables. Binary logistic regression (forward logistic regression) was used in the multivariate analysis to determine the factors associated with positive responders. Variables included in the analyses were gestational age, birth weight, sex, early PHT, PHT-definite, pre-iNO MAP, pre-iNO oxygenation index, duration of ventilation and oxygen treatment days, length of hospital stay and mortality. Statistical significance was set at $p<0.05$.

\section{RESULTS}

Overall 56 neonates received iNO at the NICU during the 4-year study. After excluding infants meeting the exclusion criteria, 44 neonates were included in the final analysis. A total of $33(75 \%)$ cases were classified as definite $\mathrm{PH}$ based on echocardiography results. Of the analysed patients, $32(72 \%)$ were in the early $\mathrm{PH}$ group, whereas $12(28 \%)$ were in the late PH group. Although mean gestational age and birth weight of the infants diagnosed with early $\mathrm{PH}$ were higher, no significant difference was observed. Clinical diagnoses of early and late PH groups are shown in Table 1. 
Table 1: Neonatal and maternal characteristics of early and late pulmonary hypertension groups

\begin{tabular}{|c|c|c|c|}
\hline & $\begin{array}{c}\text { Early PH } \\
(\mathrm{n}=32)\end{array}$ & $\begin{array}{c}\text { Late PH } \\
(\mathrm{n}=12)\end{array}$ & $\mathbf{P}$ \\
\hline $\begin{array}{l}\text { GA at birth, wk } \\
\text { median (IQR) }\end{array}$ & $36(32-38)$ & $32(26-38)$ & $0.07^{\mathrm{a}}$ \\
\hline $\begin{array}{l}\mathrm{BW}, \mathrm{g} \\
\text { median (IQR) }\end{array}$ & $2528 \pm 936$ & $1857 \pm 1129$ & $0.05^{\mathrm{b}}$ \\
\hline $\begin{array}{l}\text { Sex, n }(\%) \\
\text { Male }\end{array}$ & $20(62)$ & $6(50)$ & $0.4^{\mathrm{c}}$ \\
\hline $\mathrm{C} / \mathrm{S}$ delivery, $\mathrm{n}(\%)$ & $23(72)$ & $6(66)$ & $0.8^{\mathrm{c}}$ \\
\hline \multicolumn{4}{|l|}{ Apgar score, median (IQR) } \\
\hline $\begin{array}{l}\text { Minute } 1 \\
\text { Minute } 5\end{array}$ & $\begin{array}{l}6(5-7) \\
7(6-8)\end{array}$ & $\begin{array}{l}5(4-6) \\
6(5-7)\end{array}$ & $\begin{array}{l}0.2^{\mathrm{a}} \\
0.2^{\mathrm{a}}\end{array}$ \\
\hline Antenatal steroid, n (\%) & $6(19)$ & $3(25)$ & $0.8^{\mathrm{c}}$ \\
\hline \multicolumn{4}{|l|}{ Maternal risk factors } \\
\hline Hypertension & $4(13)$ & $3(25)$ & $0.3^{\mathrm{c}}$ \\
\hline Gestational diabetes & $3(9)$ & $1(8)$ & $0.9^{c}$ \\
\hline Abruptio plasenta & $3(9)$ & $1(8)$ & $0.9^{\mathrm{c}}$ \\
\hline PPROM & $4(13)$ & $4(33)$ & $0.1^{\mathrm{c}}$ \\
\hline Diagnosis & & & $0.1^{\mathrm{c}}$ \\
\hline MAS & $2(6)$ & & \\
\hline Sepsis & $8(25)$ & $2(17)$ & \\
\hline Diaphragmatic hernia & $9(28)$ & $3(25)$ & \\
\hline HIE & $5(16)$ & $2(17)$ & \\
\hline RDS & $6(19)$ & & \\
\hline BPD & & $4(33)$ & \\
\hline TTN & $2(6)$ & $1(8)$ & \\
\hline
\end{tabular}

${ }^{a}$ Mann-Whitney U test, ${ }^{b}$ Student $t$ test,${ }^{c}$ Chi Square test

PH: pulmonary hypertension; GA: gestational age; wk: week; IQR: interquartile range; $B W$ : birth weight; g: gram; C/S: cesarean section; PPROM: preterm prolonged rupture of membranes; MAS: Meconium aspiration syndrome HIE: hypoxic ischemic encephalopathy, RDS: Respiratory distress syndrome, BPD: bronchopulmonary dysplasia; TTN: Transient Tachypnea of the Newborn

After the infants were classified according to birth weeks, 17 (39\%) were at <34 gestation weeks (group 1) and 27 (61\%) were at >34 gestation weeks (group 2). After comparing these groups, pre-iNO, post-iNO, MAP, pre-iNO, and OI values were found to be significantly higher in group 1. Age at PH was significantly different with averages being at the third day in Group 1 and first day in Group $2(\mathrm{p}=0.04)$. As we expected, length of stay was longer in Group $1(\mathrm{p}=0.03)$. Furthermore, iNO response was better among infants with higher gestational age $(\mathrm{p}=0.04)$. Clinical and laboratory findings of the groups are presented in Table 2. 
Table 2: Clinical and laboratory findings of the groups

\begin{tabular}{|c|c|c|c|}
\hline & Grup $1(n=18)$ & Grup $2(n=26)$ & $\mathbf{p}$ \\
\hline Received surfactant, $\mathrm{n}(\%)$ & $16(89)$ & $10(39)$ & $0.001^{\mathrm{a}}$ \\
\hline Duration of ventilation (days) & $16(9-35)$ & $9(7-11)$ & $0.005^{b}$ \\
\hline $\begin{array}{l}\text { Duration of } 02 \text { treatment } \\
\text { (days) }\end{array}$ & $22(9-56)$ & $10(8-14)$ & $0.01^{b}$ \\
\hline Age at PH (days) & $3(1-15)$ & $1(1-2)$ & $0.07^{\mathrm{b}}$ \\
\hline PH- definite & $13(72)$ & $20(77)$ & $0,7^{\mathrm{a}}$ \\
\hline Duration of iNO use (hours) & $84 \pm 40$ & $88 \pm 42$ & $0.7^{\mathrm{c}}$ \\
\hline HFO at ino & $7(39)$ & $11(42)$ & $0.8^{\mathrm{a}}$ \\
\hline $\begin{array}{l}\text { Pre-iNO mean airway pressure } \\
(\mathrm{cmH} 2 \mathrm{O})\end{array}$ & $13(13-14)$ & $12(11-13)$ & $0.01^{b}$ \\
\hline Pre iNO FiO2 & $1.0(1.0-1.0)$ & $1.0(1.0-1.0)$ & $0.7^{\mathrm{b}}$ \\
\hline Pre iNO OI & $32(29-40)$ & $30(26-37)$ & $0.04^{b}$ \\
\hline $\begin{array}{l}\text { Post-iNO mean airway } \\
\text { pressure }(\mathrm{cmH} 2 \mathrm{O})\end{array}$ & $13 \pm 1$ & $12 \pm 1$ & $\mathbf{0 . 0 3}^{\mathrm{c}}$ \\
\hline Post-iNO FiO2 & $0.8(0.7-0.9)$ & $0.8(0.7-0.9)$ & $0.9^{\mathrm{b}}$ \\
\hline Post-iNO OI & $25 \pm 6$ & $22 \pm 8$ & $0.1^{\mathrm{c}}$ \\
\hline İNO responsiveness & $7(39)$ & $18(69)$ & $0.04^{\mathrm{a}}$ \\
\hline Pulmonary hemorrhage & $4(22)$ & $4(15)$ & $0.8^{\mathrm{a}}$ \\
\hline $\begin{array}{l}\geq \text { Grade } 3 \text { intraventricular } \\
\text { haemorrhage }\end{array}$ & $4(22)$ & $1(4)$ & $0.06^{\mathrm{a}}$ \\
\hline Length of hospital stay (days) & $24(9-69)$ & $15(9-19)$ & $0.04^{b}$ \\
\hline Early PH & $10(56)$ & $22(84)$ & $\mathbf{0 . 0 3}^{\mathrm{a}}$ \\
\hline Mortalite & $6(33)$ & $6(23)$ & $0.4^{\mathrm{a}}$ \\
\hline
\end{tabular}

${ }^{a}$ Chi Square test, , ${ }^{b}$ Mann-Whitney U test, ${ }^{c}$ Student-T test. PH: pulmonary hypertension, iNO: inhaled nitric oxide, HFO: high frequency ventilation, FiO2: fraction of inspired oxygen, OI: oxygenation index 
When the infants born with gestational age before 34 weeks were compared according to the iNO initiation day, duration of ventilation days, and $\mathrm{O}_{2}$ treatment days were significantly less $(\mathrm{p}=0.004$ and $\mathrm{p}=0.02$ respectively) in the early $\mathrm{PH}$ group. In early $\mathrm{PH}$ group, nine $(90 \%)$ cases were classified as definite PH based on echocardiography results and only one (10\%) from the documented pre-iNO pre-post ductal saturation difference $(\mathrm{p}=0.02)$. Although there was no statistical significance, positive response rate was higher in the early $\mathrm{PH}$ group [5/10 (50\%) vs. $2 / 8(25 \%)$ ]. Mortality was less in the early $\mathrm{PH}$ group compared to the late $\mathrm{PH}$ group (Table 3).

Table 3: Clinical and laboratory findings of the preterm infants

\begin{tabular}{|c|c|c|c|}
\hline & Early PH $(n=10)$ & Late PH $(n=8)$ & $\mathbf{p}$ \\
\hline Received surfactant, $\mathrm{n}(\%)$ & $9(90)$ & $7(88)$ & $0.9^{\mathrm{a}}$ \\
\hline $\begin{array}{l}\text { Duration of ventilation } \\
\text { (days) }\end{array}$ & $13 \pm 10$ & $57 \pm 48$ & $0.04^{\mathrm{c}}$ \\
\hline $\begin{array}{l}\begin{array}{l}\text { Duration of } \\
\text { (days) }\end{array} \\
\end{array}$ & $23 \pm 20$ & $61 \pm 53$ & $0.04^{\mathrm{c}}$ \\
\hline Age at PH (days) & $1(1-3)$ & $17(9-50)$ & $0.001^{\mathrm{c}}$ \\
\hline PH- definite & $9(90)$ & $3(38)$ & $0,02^{\mathrm{a}}$ \\
\hline Duration of iNO use (hours) & $75 \pm 42$ & $94 \pm 38$ & $0.3^{\mathrm{c}}$ \\
\hline $\mathrm{HFO}$ at ino & $3(30)$ & $4(50)$ & $0.4^{\mathrm{a}}$ \\
\hline $\begin{array}{l}\text { Pre-iNO mean airway pressure } \\
(\mathrm{cmH} 2 \mathrm{O})\end{array}$ & $13 \pm 2$ & $13 \pm 1$ & $0.8^{\mathrm{b}}$ \\
\hline Pre iNO FiO2 & $1(1-1)$ & $1(0.9-1)$ & $0.8^{\mathrm{c}}$ \\
\hline Pre iNO OI & $33 \pm 6$ & $32 \pm 7$ & $0.8^{\mathrm{b}}$ \\
\hline $\begin{array}{l}\text { Post-iNO mean airway } \\
\text { pressure }(\mathrm{cmH} 2 \mathrm{O})\end{array}$ & $13 \pm 1$ & $12 \pm 1$ & $0.6^{\mathrm{b}}$ \\
\hline Post-iNO FiO2 & $0.8 \pm 0.1$ & $0.8 \pm 0.1$ & $0.6^{\mathrm{b}}$ \\
\hline Post-iNO OI & $25 \pm 6$ & $24 \pm 5$ & $0.9^{\mathrm{b}}$ \\
\hline Pulmonary hemorrhage & $2(20)$ & $2(25)$ & $0.8^{\mathrm{a}}$ \\
\hline $\begin{array}{l}\geq \text { Grade } 3 \text { intraventricular } \\
\text { haemorrhage }\end{array}$ & $2(20)$ & $2(25)$ & $0.8^{\mathrm{a}}$ \\
\hline Length of hospital stay (days) & $16(5-56)$ & $35(18-23)$ & $0.1^{\mathrm{c}}$ \\
\hline İNO responsiveness & $5(50)$ & $2(25)$ & $0.3^{\mathrm{a}}$ \\
\hline Mortalite & $2(20)$ & $4(50)$ & $0.2^{\mathrm{a}}$ \\
\hline
\end{tabular}

${ }^{a}$ Chi Square test, , ${ }^{b}$ Student-T test, ${ }^{c}$ Mann-Whitney U test, PH: pulmonary hypertension, iNO: inhaled nitric oxide, HFO: high frequency ventilation, FiO2: fraction of inspired oxygen, OI: oxygenation index 
When all patients were evaluated, positive response rate to iNO treatment was $57 \%$, whereas in term infants, positive response rate was $70 \%$. Positive responders were more likely to be with higher GA and higher birth weight (Table 4).

Table 4: Comparision of baseline characteristics of positive responders

\begin{tabular}{|c|c|c|c|}
\hline & $\begin{array}{c}\text { Positive responder } \\
(\mathrm{n}=25)\end{array}$ & $\begin{array}{c}\text { Non-responder } \\
(\mathrm{n}=16)\end{array}$ & $\mathbf{p}$ \\
\hline $\begin{array}{l}\text { GA at birth, wk } \\
\text { median (IQR) }\end{array}$ & $36(33-39)$ & $31(26-37)$ & $0.02^{\mathrm{a}}$ \\
\hline $\begin{array}{l}\mathrm{BW}, \mathrm{g} \\
\text { median (IQR) }\end{array}$ & $2525 \pm 790$ & $2100 \pm 1253$ & $0.04^{b}$ \\
\hline $\begin{array}{l}\text { Sex, } \mathrm{n}(\%) \\
\text { Male }\end{array}$ & $15(60)$ & $11(58)$ & $0.9^{\mathrm{c}}$ \\
\hline Early PH & $20(80)$ & $12(63)$ & $0,2^{\mathrm{c}}$ \\
\hline PH-Definite & $20(80)$ & $13(68)$ & $0,4^{\mathrm{c}}$ \\
\hline Pre-ino mean airway pressure & $12(11-14)$ & $13(12-13)$ & $0,3^{\mathrm{a}}$ \\
\hline Pre-ino Oİ & $28(26-30)$ & $34(30-40)$ & $0.04^{\mathrm{a}}$ \\
\hline $\begin{array}{l}\text { Duration of ventilation } \\
\text { (days) }\end{array}$ & $9(7-12)$ & $12(8-28)$ & $0,1^{\mathrm{a}}$ \\
\hline $\begin{array}{l}\text { Duration of } 02 \text { treatment } \\
\text { (days) }\end{array}$ & $12(8-17)$ & $15(9-31)$ & $0,4^{\mathrm{a}}$ \\
\hline Length of hospital stay (days) & $15(11-28)$ & $19(9-35)$ & $0.6^{\mathrm{a}}$ \\
\hline Mortalite & $4(16)$ & $8(42)$ & $0.04^{c}$ \\
\hline
\end{tabular}

${ }^{a}$ Mann-Whitney $U$ test, ${ }^{b}$ Student-T test, ${ }^{c}$ Chi Square test GA: gestational age; wk: week; IQR: interquartile range; BW: birth weight; g: gram; PH: pulmonary hypertension, iNO: inhaled nitric oxide, OI: oxygenation index;

According to forward binary logistic regression results, only GA and birth weight were significant factors for positive responders. GA was significant risk factor with odds ratio [OR] $=1.869$ [95\% confidence interval $(\mathrm{CI}): 1.204-2.901 ; \mathrm{p}=0.005]$, whereas birth weight was preventive factor with $\mathrm{OR}=0.998(\mathrm{CI}: 0.996-0.999 ; \mathrm{p}=0.036)$ for positive responders. When the clinical diagnoses of patients who did not respond to iNO treatment were examined, it was observed that the non-responders 'rate was the highest in the diaphragmatic hernia (4/8) group in term infants and in sepsis (4/11) group in preterm infants. 


\section{DISCUSSION}

Inhaled NO therapy effectively improves oxygenation in term infants with hypoxic respiratory failure and persistent $\mathrm{PH}(4,13)$. However, the indication for iNO therapy is not well defined in preterm infants. Furthermore, the characteristics and diagnoses of infants responding to iNO treatment are not clear. In this study, we aimed to identify our iNO experience in term and preterm infants admitting at our neonatal intensive care unit throughout 4 years, the characteristics of our patient groups, and the factors associated with favourable response to iNO therapy.

The neonatal pulmonary vascular system is generally unstable. The maturation of endothelial cell function, release of vasoactive mediators, vascular wall remodelling, and smooth muscle cell differentiation are involved in the maturation process (14). Neonatal PH is caused by a variety of factors including maternal anemia, fever, lung disease, diabetes mellitus, meconium- stained amniotic fluid, perinatal asphyxia, fetal distress, and sepsis (15). iNO is a selective pulmonary vasodilator and is used for treating early persistent PH in term infants. In preterm infants, it is especially used in respiratory failure, respiratory distress syndrome (RDS), or bronchopulmonary dysplasia (BPD) that does not respond to conventional treatments (16). In our study, GA and birth weight of the neonates in early PH group were higher than the late PH group. The most frequent diagnosis in the early PH cohort was diaphragmatic hernia, whereas the most frequent in the late PH cohort was BPD.

The National Institutes of Health consensus panel and the American Academy of Pediatrics Committee on Fetus and Newborn has reported that there is no sufficient evidence to recommend the routine use of iNO in preterm infants with GA $<34$ weeks $(17,18)$. However, in the guideline published by the American Heart Association and the American Thoracic Society, it was reported that iNO therapy can be beneficial especially for EMR and oligohydramnios infants with PH secondary to hypoxemia in preterm (19). In the recent years, there have been studies showing that iNO use is effective in preterm infants at least as much as in term infants (20). Due to these conflicting reports, we evaluated our own patient group. Majority of our patient group was formed by infants with GA >34 weeks. Early PH diagnosis was apparently defined more for infants with GA > 34 weeks. This was most probably caused by the diagnoses of the patients in this group with hypoxic ischemic encephalopathy and diaphragmatic hernia encountered with early $\mathrm{PH}$ clinic. As expected, received surfactant rate, 
duration of ventilation days, length of hospital stays and iNO responsiveness of the group with GA $<34$ weeks were higher. When the OI and MAP values of the groups before and after iNO were compared, it was observed that pre-iNO MAP and OI values were higher in the infants with GA <34 weeks. This made us consider that we may have been late in starting the iNO treatment in preterm infants which decreased our iNO treatment success in preterm infants. In a recently published study, it was shown that patients between OI 15-25 have better clinically significant improvements and mortality compared to the OI of $>25$ group (21). Further studies are needed with large case series comprising various OI groups to prove this hypothesis.

In preterm infants, unlike term neonates, we observed pulmonary diseases to be a secondary particularly to RDS. The prevalence of RDS causing oxygenation failure has now decreased after antenatal steroids and postnatal surfactant therapy (22). In preterm infants, other than RDS, sepsis, persistent fetal circulation, or BPD can damage the pulmonary vascular structure which may clinically encountered PH. (10). In animal studies, it was shown that NO synthase expression decreases in the epithelium of small airways as well as in the endothelium of the distal pulmonary artery in chronic pulmonary disease (23). At the same time tracheal aspirate analysis in hypoxemic PH preterm infants with PPROM or sepsis has shown a transient defect in endogenous nitric oxide generation (22). In our study, RDS along with PH secondary to sepsis in the early period and PH associated with BPD in the late period were detected in the preterm infants. In compliance with the literature, PPROM and oligohydramnios prevalence were higher in the preterm group due to the need for iNO. Due to this treatment is off-label in preterm infants with GA $<34$ weeks, there are very few studies concerning this area $(6,10,16)$. In our study, early PH group with GA <34 weeks were monitored with less oxygen treatment and ventilation days and definite-PH diagnoses were more. This was caused by the late $\mathrm{PH}$ group consisting mostly of the BPD diagnosis and these being started with the treatment without the need for definite diagnosis with ECHO.

iNO response in PH treatment is associated with gestational age in neonates. Cochrane metaanalysis states that iNO therapy in term and near-term infants, OI decreased by a mean of 15.1 within 30-60 min after the start of therapy (12). However, Cochrane meta-analysis states that in preterm infants, early routine use of iNO did not appear to be effective but later use of iNO to prevent BPD could be effective (11). In our study, the positive response rate to iNO treatment was $57 \%$ in patients who received iNO and $70 \%$ for term infants. The evaluation of factors associated with iNO responsiveness according to forward binary logistic regression 
analysis showed that only GA and birth weight were significant factors for positive responders. GA was significant risk factor, whereas birth weight was preventive factor for positive responders. Moreover, preliminary OI values and mortality rates in the iNO responder group were lower. When the clinical diagnoses of the patients who were nonresponders to the iNO treatment were evaluated, it was observed as consistent with the literature that the worst responses were in the diaphragmatic hernia group in term infants and the sepsis group in the preterm infants.

There are limitations of this study where first one is its retrospective design; however, we were able to use a highly reliable neonatal database that identified all the infants with PH. As a second one, we did not have a control group of untreated infants, so we cannot confirm the impact of iNO on neonatal outcomes. In addition, we could not determine subgroups of different pre-iNO OI and MAP values which is the third limitation. As a final one, our sample size was relatively small due to iNO use which is limited in the NICU and even less in preterm infants. Despite these limitations, there are powerful strengths of our study that are an important addition to the limited clinical study data available in preterm infants with $\mathrm{PH}$ and provide valuable insight into the actual use of iNO.

Conclusion: In conclusion, iNO is used for treating neonatal PH in term and preterm infants. As it is an off-label treatment in preterm infants, the parameters for iNO treatment initiation decision are quite high. This can decrease iNO treatment success in neonates in critical condition who would not have the chance to be given ECMO, such as preterm infants. Thus, iNO use should be optimized in preterm infants. Therefore, there is a need for large case series-studies with subgroups of various diagnoses and pre-iNO parameters.

Conflict of Interest: No potential conflict of interest was reported by the authors.

Funding: No funding was received. 


\section{REFERENCES}

1.Furchgott RF, Zawadzki JV. The obligatory role of endothelial cells in the relaxation of arterial smooth muscle by acetylcholine. Nature. 1980;288(5789):373-6.

2.Pepke-Zaba J, Higenbottam TW, Dinh-Xuan AT, Stone D, Wallwork J. Inhaled nitric oxide as a cause of selective pulmonary vasodilatation in pulmonary hypertension. Lancet. 1991;338(8776):1173-4.

3.Sokol GM, Konduri GG, Van Meurs KP. Inhaled nitric oxide therapy for pulmonary disorders of the term and preterm infant. Semin Perinatol. 2016;40(6):356-69.

4.Roberts JD, Jr., Fineman JR, Morin FC, 3rd, Shaul PW, Rimar S, Schreiber MD, et al. Inhaled nitric oxide and persistent pulmonary hypertension of the newborn. The Inhaled Nitric Oxide Study Group. N Engl J Med. 1997;336(9):605-10.

5.Farrow KN, Fliman P, Steinhorn RH. The diseases treated with ECMO: focus on PPHN. Semin Perinatol. 2005;29(1):8-14.

6.Dani C, Corsini I, Cangemi J, Vangi V, Pratesi S. Nitric oxide for the treatment of preterm infants with severe RDS and pulmonary hypertension. Pediatr Pulmonol. 2017;52(11):1461-8.

7.Chandrasekharan P, Kozielski R, Kumar VH, Rawat M, Manja V, Ma C, et al. Early Use of Inhaled Nitric Oxide in Preterm Infants: Is there a Rationale for Selective Approach? Am J Perinatol. 2017;34(5):428-40.

8.Ellsworth MA, Harris MN, Carey WA, Spitzer AR, Clark RH. Off-label use of inhaled nitric oxide after release of NIH consensus statement. Pediatrics. 2015;135(4):643-8.

9.Soraisham AS, Harabor A, Shivananda S, Alvaro R, Ye XY, Lee SK, et al. Trends and Variations in the Use of Inhaled Nitric Oxide in Preterm Infants in Canadian Neonatal Intensive Care Units. Am J Perinatol. 2016;33(7):715-22.

10. Baczynski M, Ginty S, Weisz DE, McNamara PJ, Kelly E, Shah P, et al. Short-term and long-term outcomes of preterm neonates with acute severe pulmonary hypertension following rescue treatment with inhaled nitric oxide. Arch Dis Child Fetal Neonatal Ed. 2017;102(6):F508-F14.

11.Barrington KJ, Finer N, Pennaforte T. Inhaled nitric oxide for respiratory failure in preterm infants. Cochrane Database Syst Rev. 2017;1:CD000509.

12.Barrington KJ, Finer N, Pennaforte T, Altit G. Nitric oxide for respiratory failure in infants born at or near term. Cochrane Database Syst Rev. 2017;1:CD000399. 
13.Neonatal Inhaled Nitric Oxide Study G. Inhaled nitric oxide in full-term and nearly full-term infants with hypoxic respiratory failure. N Engl J Med. 1997;336(9):597-604.

14.Sood BG, Wykes S, Landa M, De Jesus L, Rabah R. Expression of eNOS in the lungs of neonates with pulmonary hypertension. Exp Mol Pathol. 2011;90(1):9-12.

15.Simpson CM, Smolich JJ, Shekerdemian LS, Penny DJ. Urotensin-II contributes to pulmonary vasoconstriction in a perinatal model of persistent pulmonary hypertension of the newborn secondary to meconium aspiration syndrome. Pediatr Res. 2010;67(2):150-7.

16.Chock VY, Van Meurs KP, Hintz SR, Ehrenkranz RA, Lemons JA, Kendrick DE, et al; NICHD Neonatal Research Network. Inhaled nitric oxide for preterm premature rupture of membranes, oligohydramnios, and pulmonary hypoplasia. Am J Perinatol. 2009;26(4):317-22.

17. Cole FS, Alleyne C, Barks JD, Boyle RJ, Carroll JL, Dokken D, et al. NIH Consensus Development Conference statement: inhaled nitric-oxide therapy for premature infants. Pediatrics. 2011;127(2):363-9.

18.Kumar P, Committee on F, Newborn, American Academy of P. Use of inhaled nitric oxide in preterm infants. Pediatrics. 2014;133(1):164-70.

19.Abman SH, Ivy DD, Archer SL, Wilson K, Committee AAJGfPPH. Executive Summary of the American Heart Association and American Thoracic Society Joint Guidelines for Pediatric Pulmonary Hypertension. Am J Respir Crit Care Med. 2016;194(7):898-906.

20.Suzuki S, Togari H, Potenziano JL, Schreiber MD. Efficacy of inhaled nitric oxide in neonates with hypoxic respiratory failure and pulmonary hypertension: the Japanese experience. J Perinat Med. 2018;46(6):657-63.

21.Rhine WD, Suzuki S, Potenziano JL, Escalante S, Togari H. An Analysis of Time to Improvement in Oxygenation in Japanese Preterm and Late Preterm or Term Neonates With Hypoxic Respiratory Failure and Pulmonary Hypertension. Clin Ther. 2019;41(5):910-9.

22.Aikio O, Metsola J, Vuolteenaho R, Perhomaa M, Hallman M. Transient defect in nitric oxide generation after rupture of fetal membranes and responsiveness to inhaled nitric oxide in very preterm infants with hypoxic respiratory failure. J Pediatr. 2012;161(3):397-403 e1.

23.MacRitchie AN, Albertine KH, Sun J, Lei PS, Jensen SC, Freestone AA, et al. Reduced endothelial nitric oxide synthase in lungs of chronically ventilated preterm lambs. Am J Physiol Lung Cell Mol Physiol. 2001;281(4):L1011-20. 